\title{
Kişisel Sağlık Verilerinin Korunmasında İdarenin Hukuki Sorumluluğu
}

\author{
Veli DURMUȘ*
}

$\ddot{O} \mathbf{z}$

Sağlık kuruluşları, kişisel sağlık verilerinin yoğun olarak işlendiği ve muhafaza edildiği yerlerdir. Her muayene ve tedavi esnasında bu veriler yeniden toplanmakta ve işlenmektedir. Bir kişinin ruhsal ve fiziksel sağlığına ilişkin her türlü bilgi kişisel sağllk verisi kapsamında değerlendirilebilir. Bu nedenle, her hastanın muayene ve tedavi sürecinde idare ile paylaşmak zorunda olduğu veriler bulunmaktadır. Bu veriler bireyin sağlık ve cinsel durumuna ait olabileceği gibi sosyo-demografik nitelikte de olabilir. Dijital teknolojinin gelişmesiyle birlikte, kişisel sağlık verilerinin elde edilmesi ve işlenmesi de kolaylaşmışır. Ancak bu durum aynı zamanda kişisel sağlık verilerinin rahatlıkla ihlal edilmesine yol açmıştır. Hassas veri niteliğinde olan bu bilgilerin korunması Anayasada ve uluslararası düzeyde çeşitli sözleşmelerde temel hak olarak düzenlenmiştir. Bilişim teknolojisinin gelişmesiyle birlikte, kişisel veri güvenliğinin sağlanması ve idare tarafından kapsamlı koruma önlemlerinin alınması gerekmektedir. Aksi takdirde idarenin veya veri sorumlularının kişisel sağlık verilerinin korunmasında hukuki sorumluluğu doğacaktır. Bu derleme makalenin amacı, sağlık kurum ve kuruluşlarında kişisel sağlık verilerinin korunması ve mahremiyetin sağlanmasının önemini ortaya koyarak Avrupa İnsan Hakları Mahkemesi ve Danıştay kararları 1şı̆̆ında idarenin hukuki sorumluluğunu açıklamaktır. Ayrıca, idari sağlık faaliyetlerinin yürütülmesi sırasında kişisel sağlık verilerinin korunmasına yönelik öneriler sunulmuştur. Anahtar Kelimeler: Kişisel Sağlık Verisi, Kişisel Verilerin İşlenmesi, Gizlilik, İdare, Sağlık Hizmetleri.

\section{Abstract}

\section{Legal Responsibility of Administration for the Protection of Personal Health Data}

Health institutions are places where personal health data is intensively processed and maintained. These data are collected and processed during each examination and treatment. All kinds of information regarding the mental and physical health of a person may be considered within the field of personal health data. Hence, there are some data that every patient has to share with the administration in the process of examination and treatment. This data may be related to the health and sexuality of the individual and socio-demographic. It has become easier to obtain and process the personal health data. The protection of information is regulated as a fundamental right in various agreements at international level. With the development of information technology, it is necessary to provide personal data security and to take comprehensive protection measures by the administration. This review article aims to to explain the legal responsibility of the administration in the light of the decisions of the European Court of Human Rights and the Supreme Administrative Court by presenting the importance of ensuring privacy and the protection of personal health data in health care providers. In addition, suggestions for the protection of personal health data were presented during the conduct of administrative health activities.

Keywords: Personal Health Data, Personal Data Processing, Privacy, Administration, Health Services.

\section{Geliș tarihi: 02.06.2020 Kabul tarihi: 14.12.2020}

$\mathrm{H}$ er bireyin toplumda yer edinmesini sağlayan kendine özgü bir takım kişisel verileri bulunmaktadır. Bu veriler aslında bireylerin toplumsal düzeyde tanınmasına, işlem görmesine, belirlenebilir olmasına imkan tanımaktadır. Dünya üzerinde her bireye ait kişisel verilerin olduğu düşünüldüğünde, nüfus artışının doğal sonucu olarak verilerin de giderek artması ve çeşitlenmesi kaçınılmazdır. Kişiye ait verilerin toplanması, elde edilmesi ve paylaşılması eskilere dayanmaktadır. Bundan önceki yüzyıllarda bilgi yetersizliği, bilgiye erişimde yaşanan güçlükler ve verilerin depolanması bir sorun iken (1), günümüzde ise bilgi karmaşası yüzünden nitelikli veriye erişimde zorluklar yaşanmaktadır (2). Ayrıca internet ve bulut teknolojisi aracılığıyla küresel düzeyde bağlantıların gelişimi sayesinde, veri işleme, muhafaza etme ve transferini gerçekleştirme çok daha hızlı ve yaygın hale gelmiştir $(3,4)$. Bu sayede etkileşim alanı genişleyen kişsisel verilerin güvenliği ve korunması bir hak olarak ulusal ve uluslararası hukuki metinlerde yerini almıştır. Bu kapsamda, 108 sayılı Avrupa Konseyi Sözleşmesi, Avrupa Birliği Veri Koruma Direktifi gibi uluslararası belgeler ile birlikte Birleşmiş Milletler, Ekonomik Kalkınma ve İşbirliği Örgütü-BMEKIÖ (OECD) gibi uluslararası nitelikteki kuruluşların kişisel verilerin korunmasına yönelik düzenlemeleri bulunmaktadır. Son olarak, Avrupa Parlamentosu tarafından 27 Nisan 2016 tarihinde kabul edilen ve 2018 yılında ise bütün üye ülkeler için bağlayıcı hale gelen 679 sayılı Avrupa Birliği Genel Veri Koruma Tüzüğü-ABGVKT (General Data Protection Regulation, GDPR) yürürlüğe girmiştir. Türkiye'de ise 1982 tarihli Türkiye Cumhuriyeti Anayasası başta olmak üzere, 24 Mart 2016 tarihli 6698 sayılı Kişisel Verilerin Korunması Kanunu (KVKK) ile birlikte çeşitli yönetmelik ve genelgeler bulunmaktadır. Bu düzenlemelerle temel olarak, mahremiyetin sağlanması, kişisel verilerin kanunlara tabi olarak elde edilmesi ve işlenmesi, bunlara ilişkin denetim ve kontrol mekanizmalarının oluşturulması amaçlanmıştır $(5,6)$. Böylece kişisel veri kavramının hukuki bir çerçeve içerisinde ele alınması sağlanmışıı. ABGVKT ve KVKK tarafından kişisel veri kavramı, kısaca gerçek kişiyle ilişkili olan her türlü bilgi şeklinde tanımlanmış olmasına rağmen, bu tanım ile birlikte aslında çok geniş bir bilgi yelpazesi oluşmuştur. Kişiye ait hangi tür bilgilerin kişisel veri olarak değerlendirileceği, her ülkenin iç hukukunda yapılacak düzenlemelerle ve verilecek hukuki kararlarla şekil alacaktır (7). Anayasa Mahkemesi’nin 2017 tarihli bir kararına göre; kişisel veri kavramı "kişinin sadece kimliğini ortaya koyan ad, soyad, doğum tarihi ve doğum yeri gibi bilgilerinden değil aynı zamanda telefon numarası, pasaport numarası, motorlu taşıt plakası, sosyal güvenlik numarası, öz geçmiş, görüntü ve ses kayıtları, resim, parmak izleri genetik bilgiler ile sağllk bilgileri, e-posta adresi, Internet Protokol (IP) adresi, alışkanlıklar, hobiler, grup üyelikleri, aile bilgileri gibi kişiyi belirlenebilir kılan bütün verilerden oluşmaktadır” (8).

Kişisel verilerin, özel hayatın gizliliğine ve bireylerin mahremiyetine ilişkin olması bakımından elde edilmesi, işlenmesi ve korunması önemlidir. Çünkü kişiye ait her bir bilgi o bireyin özel hayatına özgüdür.

* Dr., Marmara Üniversitesi, Sağlık Bilimleri Enstitüsü, Maltepe, İstanbul/Türkiye. Orcid No: 0000-0001-6124-6109. e-posta: velidurmus@gmail.com 
Bu nedenle, Avrupa İnsan Hakları Sözleşmesi (AİHS), Kişisel ve Siyasal Haklar Uluslararası Sözleşmesi, İnsan Hakları Evrensel Bildirgesi gibi uluslararası nitelikteki düzenlemeler insan haklarından olan özel hayatın gizliliğini kabul ederek mahremiyetin sağlanması amacıyla kişisel verilerin korunması hususuna önem vermektedirler. Anayasa'da ise bu kavram özel hayatın gizliliği (madde 20) kenar başlığı altında 2010 yılında yapılan bir değişiklikle hem bu verilerin korunmasını, düzeltilmesini ve silinmesini talep etme hakkı olarak tanımlanmış hem de bunun özel hayatın bir gereği olduğu hüküm altına alınmıştır. Bu kapsamda, bireyin kişiliğini serbestçe geliştirebilmesi ve insan onurunun korunması hakkının özel bir biçimi olan kişisel verilerin korunması hakkı, toplanması ve işlenmesi esnasında kişinin hak ve özgürlüklerini koruma altına almayı amaçlar. Bu hakkın korunması için, 6698 sayılı Kanun gereği Kişisel Verileri Koruma Kurumu oluşturulmuştur. Kurumlaşmadaki temel amaç, “Anayasa'da öngörülen kişi temel hak ve hürriyetlerini en üst düzeyde koruma ve gelişmesine katkı sağlama ile birlikte toplumsal bir farkındalık oluşturmak, kişisel verilerin korunması ilke ve esaslarını içselleştirerek bu ilkelerin ne şekilde hayata geçirileceği noktasında tüm sektörlere yol göstermektir" (madde 1).

Birçok yasal düzenlemelerde kişisel verilerin gizliliğine vurgu yapılmakla beraber, 2014 y1lında Anayasa Mahkemesi tarafından verilmiş bir kararda bunun nedeni ayrıntılı olarak açıklanmıştır (9). Buna göre,

"Kişisel verilerin korunması hakkı, kişinin insan onurunun korunmasının ve kişiliğini serbestçe geliştirebilmesi hakkının özel bir biçimi olarak, bireyin hak ve özgürlüklerini kişisel verilerin işlenmesi sırasında korumayı amaçlamaktadır. Bilişim teknolojilerindeki gelişmeler sonucunda, geleneksel yöntemlerle mümkün olmayan çok sayıda verinin toplanabilmesi; daha önce birbirinden ilişkisiz şekilde tutulan pek çok verinin merkezi olarak bir araya getirilebilmesi; verilerin, veri eşleştirme ve veri madenciliği gibi ileri teknolojik imkânlarla analize tabi tutulmak suretiyle, veriden yeni veriler üretme kapasitesinin artmasl; verilere erişim ve veri transferinin kolaylaşması; kişisel verilerin ticari işletmeler için klymetli bir varlık niteliği kazanması neticesinde, özel sektör unsurlarınca yaratılan risklerin daha yaygın ve önemli boyutlara ulaşması ve terör ve suç örgütlerinin kişisel verileri ele geçirme yönündeki faaliyetlerinin artması gibi etkenler, günümüzde kişisel verilerin en üst seviyede korunmasinı zorunlu kilmaktadır."

Kişisel verilerin korunmasına ilişkin yapılacak olan her türlü usulün ancak kanunla düzenlenebileceği Anayasa'nın 20. maddesinde açıkça belirtilmiştir. Böylece anayasal güvence altına alınarak, kişisel verilerin korunması hakkı idarenin keyfi müdahalelerine karşı koruma altına alınmıştır. Koruyucu, rehabilite edici, tedavi ve teşhis hizmetlerinin Türkiye genelinde istenilen seviyeye ulaştırılması amacıyla, kamu ve özel nitelikteki sağlı kurum ve kuruluşları arasında iş birliği ile koordinasyon görevi idare tarafından yerine getirilmektedir. Sağlık Bakanlığı tarafından, 21 Haziran 2019 tarihli ve 30808 numaralı Resmi Gazete'de yayımlanarak yürürlüğe giren Kişisel Sağlık Verileri Hakkında Yönetmelik esaslarınca, kişisel verilerin korunması ve veri mahremiyetinin sağlanmasına yönelik düzenlemeler yetki bakımından idare olarak Sağlık Bakanlığı tarafından belirlenmektedir (10). Anayasa'nın 20. maddesinde yer alan özel hayatın gizliliği ile 5. maddesinde yer alan devletin temel amaç ve görevleri ile birlikte değerlendirildiğinde, kişisel sağlık verilerinin korunması konusunda idarenin pozitif yükümlülükleri olduğu anlaşılmaktadır. Dünya genelinde ele alınması gereken en önemli konulardan birisi olarak görülen kişisel sağlık verilerinin, teknolojiye uyum ile birlikte dijitalleşmesi sonucu veri mahremiyeti ve bilgi güvenliğinin idare tarafından sağlanması önemlidir $(11,12)$. Bu çalışmada böylesi önemli bir konunun kanuni çerçeve içerisinde idare tarafindan ele alınan kişisel sağlık verilerinin önemi vurgulanmaktadır. Bu nedenle öncelikle verilerin toplanması, işlenmesi, denetimi, paylaşılması ve korunması bağlamında ulusal ve uluslararası hukuki düzenlemeler aracılığıyla yasal çerçeve açıklanmış ve ardından idarenin kişisel sağlık verilerini koruma yükümlülüğü kapsamında Danıştay ve Avrupa İnsan Hakları Mahkemesi (AİHM) kararları incelenmiştir. Son olarak, sağlık idarelerinde bu konuda hassasiyet gerektiren noktalar vurgulanmıştır.

\section{Sağllk Hizmetlerinde Kişisel Veri Kavramı}

Sağlık hizmetleri, kişilerin öncelikle sağlıklarını koruyucu, tedavi ve rehabilite edici tıbbi hizmetler sağlayarak sağlıklı ve uzun yaşamalarını sağlamak ile birlikte genel sağlık düzeyini toplumsal olarak yükseltmek amacıyla yapılan çalışmalardır (13,14). Sağlık Hizmetlerinin Sosyalleştirilmesi Hakkındaki Kanun (1961 tarihli ve 224 sayılı)'a göre ise sağlık hizmetleri, “insan sağlığına zarar veren çeşitli faktörlerin yok edilmesi ve toplumun bu faktörlerin tesirinden korunması, hastaların tedavi edilmesi, bedeni ve ruhi kabiliyet ve melekeleri azalmış olanların işe alıştırılması; yani rehabilitasyonu için yapılan tıbbi faaliyetlerdir" (madde 2). Uluslararası bir kavram olarak Dünya Sağlı Örgütü (DSÖ) bu kavramı daha geniş yorumlayarak, önleyici ve geliştirici sağlık hizmetlerinden teşhis, rehabilitasyon, palyatif bakım, hastane bakımı, bireysel ve toplumsal düzeyde bakım hizmetlerine kadar hasta merkezli güvenli, ulaşılabilir ve yüksek kaliteli hizmetler olarak tanımlamıştır (15). İnsan ve toplum için böylesi bir öneme sahip sağlık hizmetleri, aslında hassas bilgi niteliğinde olan kişisel sağlık verilerinin en çok muhafaza edildiği alandır (16).

Kişisel veri kısaca kişiyi diğerlerinden ayırt eden, özünde kimliğini ortaya koyan, ona ait ekonomik, sosyal, mesleki ve sağlık dahil bütün bilgiler olarak tanımlanabilir. Dolayısıyla, kişiyi tanımlayan ve şahsa münhasır olan doğum tarihi, medeni durum, hastalık bilgisi, telefon rehberi, parmak izi ve hatta sosyal paylaşım sitelerinde paylaştığı fotoğraf, yazı, ses ve her türlü görsel kayıtlar bu kapsamda değerlendirilir (17). Kişisel veri kavramı yanında hukuki nitelik olarak farklılığı belirtmek üzere, ABGVKT'de hassas veri veya 6698 sayılı Kanunda özel nitelikli veri kavramları kullanılmaktadır. Özel nitelikli veya hassas veriler, kişisel veri kapsamında elde edilmesi, işlenmesi ve korunması için daha dikkatli olunması gereken, aynı zamanda daha çok koruma uygulaması gerektiren bir veri grubu olarak tanımlanabilir (18). Her ne kadar birbirinden farklı iki kavram gibi kullanılsa da, tanımlamalarda anlam ve amaç benzerliğinin olduğu görülmektedir. KVKK (madde 6) ve Kişisel Verileri Koruma Kurumu tarafından verilen bir kararda (19), özel nitelikli veri kavramı kullanılmasına rağmen, bu çalışmada en yaygın kullanım şekline sahip olan hassas veri kavramı tercih edilmiştir (20-22).

Özel yaşamın gizliliğinin ihlal edilmesi sonucu, bireylerin ayrımcılığa uğramasına veya mağdur olmasına neden olabilen hassas veriler, doğrudan veya dolaylı yollarla bireylerin ten rengini, etnik kökenini, felsefi ve dini inançlarını, politik görüşlerini, sendika üyeliğini, mahkûmiyetlerini, sağlık ve cinsel yaşamını ortaya çıkaran veriler olarak tanımlanabilir (22). 
Hassas veri niteliğinde olan kişisel sağlık verisi, Sağlık Bakanlığı tarafından "kimliği belirli ya da belirlenebilir gerçek kişinin fiziksel ve ruhsal sağlığına ilişkin her türlü bilgi ile kişiye sunulan sağlık hizmetleriyle ilgili bilgileri” olarak tanımlanmıştır (10). KVKK' da yer alan tanımına bakıldığında daha geniş kapsamlı ifade edildiği görülmektedir (madde 3). Diğer bir deyişle, kişisel verilerin unsurları, nelerin kişisel veri olarak kabul edildiği gibi hususlar tahdidi olarak yasal düzenlemede sayılmamıştır. Tanıma uyan her türlü veri kişisel veri olarak kabul edilebilmektedir. Dolayısıyla, bir kimsenin sağlık durumuna ilişkin tıbbi tanıya yönelik tetkik ve konsültasyonlar, semptom (belirti) ve fiziki muayene bulguları, kişinin her türlü sağlık istatistikleri bu kapsamda yer alabileceği gibi sağlık amaçlı kullanılan her türlü biyometrik (dirimölçümsel) veriler de (kişiye ait avuç içi ve parmak izi, yürüyüş biçimi, yüz, retina, imza, iris, ses, kulak, el damarı, DNA yapısı veya vücut kokusu vb.) kişisel sağlık verisi olarak değerlendirilebilir.

Birçok Avrupa ülkesinde olduğu gibi, Türkiye'de de kişisel verilerin korunmasında çeşitli yasal düzenlemeler yapıllmış olup, hassas veriler arasından da sağlık verilerinin korunmasına büyük bir önem verilmiştir (18,22). Buna göre, 6698 sayılı Kanun hassas verilerin işlenme şartlarını sıralarken "sağlık ve cinsel hayat dışındaki kişisel veriler, kanunlarda öngörülen hâllerde ilgili kişinin açık rızası aranmaksızın" işlenebileceğini açıkça belirtmiştir (madde 5). Kanun, sağlık verilerinin işlenmesi için ise ilgilinin açık rıza şartını aramıştır (madde 6). Ancak kanun koyucu bu şartın sağlık ve cinsel hayata ilişkin kişisel verilerin işlenmesine yönelik bazı istisna durumlar sıralamıştır. Buna göre, "kamu sağlığının korunması, koruyucu hekimlik uygulamaları, tıbbi teşhis, tedavi ve bakım hizmetlerinin yürütülmesi, sağlık hizmetleri ile finansmanının planlanması ve yönetimi gibi amaçlar nedeniyle yetkili kişi, kurum ve kuruluşlar tarafından ilgilinin açık rızası aranmaksızın kişisel sağlık verileri işlenebilir”. Ayrıca kişisel sağlık verilerinin işlenmesi sırasında yürürlüğe giren yasal düzenlemelerin yanı sıra Kişisel Verileri Koruma Kurulu tarafından belirlenen yeterli derecede koruyucu önlemlerin alınması gerektiği, Kişisel Sağlık Verileri Hakkında Yönetmeliğin 18. maddesinde açıkça ifade edilmiştir.

\section{Ulusal ve Uluslararası Düzenlemelerde Kişisel Sağlık Verilerinin Korunması}

Kişisel veriler arasında önemli bir yere sahip olan sağlık verilerinin korunması temel hak ve özgürlüklerin korunması kapsamında değerlendirildiğinden, ulusal ve uluslarararası düzeyde pek çok yasal düzenlemelerde ele alınmıştır. Tarihsel süreç ve teknolojinin gelişimi karşısında bilgi işlem teknolojilerinin yaygınlaşması ve veri transferinin giderek artması, hukuki, iktisadi ve sosyal bakımdan ülkelerarası önem gerektiren bir durum haline gelmiştir (23). Bu nedenle, ülkelerin veri korumaya yönelik hukuki ve idari altyapılarını düzenleyici bir takım veri koruma usul ve esasları oluşturulmuştur. Bu başlık altında öncelikle kişisel sağlık verilerini de kapsayan kişisel verilerin korunması ile ilgili ulusal düzeyde yapılan yasal düzenlemeler norm hiyerarşisine göre incelenmiştir. Daha sonra Türkiye içinde önemli olan Avrupa Birliği’nin çıkarmış olduğu uluslararası hukuki düzenlemeler üzerinde durulmuştur.

Türkiye, kişisel verilerin korunmasına yönelik ilk uluslararası belge olan 1981 tarihli "108 sayılı Kişisel Verilerin Otomatik İşleme Tabi Tutulması Karşısında Bireylerin Korunmasına Dair Sözleşme”yi imzalayan ülkelerden birisi olmasına rağmen, buna yönelik iç hukukta gerekli düzenleme yapılmadığından onaylanmamıştır (24). Buna rağmen, Türkiye Cumhuriyeti Anayasası'nda kişisel verilerin korunması konusu ilk olarak 2010 yılında yapılan değişsiklikle “özel hayatın gizliliği ve korunması" kenar başlığını taşıyan 20. maddesinde işlenmiştir. Bu madde ile kişisel verilerin (sağlık ile ilgili verilerde dahil) korunmasına yönelik usul ve esaslar kanunla düzenlenerek, anayasal bir hak olarak güvence altına alınmıştır. Anayasada yer alan bu normatif temele bağlı olarak altı yıl sonra 2016 tarihli "6698 sayılı Kişisel Verilerin Korunması Kanunu” yayımlanarak yürürlüğe girmiştir. Kişisel verilerin korunması konusu birçok faaliyet alanı ile birlikte kamu kuruluşlarını ve özel kurumları ilgilendirmesi nedeniyle bir çerçeve kanun olarak hazırlanmıştır. Böylesi bir kanunun oluşturulmasındaki temel amaç, yaşanan çok sayıda yasal sıkıntıların önüne geçmektir. 6698 sayılı Kanun gerekçesinde belirtildiği üzere, "2005 tarihli ve 5237 sayılı Türk Ceza Kanunu (TCK)'nun 135 - 140. maddelerinde kişisel verilerin hukuka aykırı olarak elde edilmesi, kaydedilmesi veya ifşa edilmesi fiillerinin suç olarak düzenlendiği ve yaptırıma bağlandığı, ancak kişisel verilerin işlenmesine yönelik özel bir kanun bulunmaması sebebiyle, bu fiillerin ne zaman hukuka aykırı ne zaman hukuka uygun olduğunun belirlenmesinde tereddütler yaşandığı" vurgulanmıştır (6). Danıştay’ın 2017 tarihinde vermiş olduğu bir kararın gerekçesinde ise "kişisel verilerin korunmasına yönelik bir kanuni düzenleme olmamasının uluslararası ilişkiler açısından da sorunlar yarattığı, EUROPOL (Avrupa Polis Bürosu-European Police Office), EUROJUST (Avrupa Birliği Ceza Adaleti İşbirliği Ajansı-European Union Agency for Criminal Justice Cooperation) gibi Avrupa kurumları ile ilişkileri sekteye uğrattığı, sağlık kuruluşlarınca tutulan kişisel verilerin güvenliğinin sağlanmasında yeterli yasal önlem olmamasının Avrupa İnsan Hakları Mahkemesi tarafından özel hayatın gizliliğine müdahale olarak kabul edildiği ve bu nedenle ihlal kararları verildiği” belirtilmektedir (25). Sonuç olarak, 108 sayılı Sözleşmenin iç hukuka uyarlanması 2016 tarihli 6698 sayılı Kanun aracılığıyla olmuştur (26).

Sağlık hizmetleri alanında 6698 sayılı Kanun uyumuna yönelik Sağlık Bakanlığı tarafından bazı yasal düzenlemeler yapılmıştır. Uluslararası sağlık turizmi ve turistin sağlı̆̆ kapsamında yürütülecek sağlık hizmetlerine ilişkin usul ve esasları belirlemek üzere "Uluslararası Sağlık Turizmi ve Turistin Sağlı̆̆1 Hakkında Yönetmelik", 13.07.2017 tarih ve 30123 sayılı Resmi Gazete'de yayımlanarak yürürlüğe girmiştir. Söz konusu Yönetmeliğin kişisel verilerin korunması ve aktarılması hükmünü düzenleyen 5. maddesinin altıncı fikrası gereği 06.07.2017 tarihinde yürütmesi durdurulan "Kişisel Sağlık Verilerinin İşlenmesi ve Mahremiyetinin Sağlanması Hakkında Yönetmelik”e atıfta bulunması, gerekse 6698 sayılı Kanun 22 . maddesi 1.fikrasının (h) bendi uyarınca "Kişisel Verileri Koruma Kurulu'nun görüşü alınmadan hazırlandığı ve yürürlüğe konulduğu gerekçesiyle yürütmesinin durdurulmasına" karar verilmiştir (27). Bu Yönetmelikte meydana gelen yasal boşluğu düzenlemek amacıyla, söz konusu Yönetmeliğin ilgili 5. ve 6. maddeleri, 6698 sayılı Kanun ile normatif uyum sağlayarak yeniden düzenlenmiştir.

Sağlık Bakanlığı tarafından "sağlık kuruluşlarından toplanan sağlık verilerine vatandaşların ve sağlık profesyonellerinin internet ve mobil cihazlar üzerinden erişebilmelerine firsat tanınmasının yanı sıra bilimsel ve istatistiksel değerlendirmeler için önemli bir kaynak işlevi sağlamak" amacıyla 05.02.2015 tarihinde Sağlık Bakanlığı tarafindan 2015/5 numaralı “e-Nabız 
Projesi” konulu Genelge yayımlanarak uygulamaya konulmuştur. Söz konusu Genelge ile “fert ve toplum sağlığının korunması, geliştirilmesi ve iyileştirilmesi için kişisel sağlık kayıtlarının gizlilik, güvenlik, bütünlük ve mahremiyetinin korunarak kişilerin kendileri tarafından kendi dijital sağlık kayıtlarına erişebilmesine imkân sağlayacak olan e-Nabız adı verilen Sağlık.Net Online Sistemi” kurulmuştur. Ancak Sağlık Bakanlığı'nın bu Genelgesi uygulamaya girdiği tarihte kanun seviyesinde kişisel verilerin işlenmesine yönelik bir yasal düzenleme olmaması nedeniyle, 2017 tarihinde Danıştay 15. Dairesi tarafından verilen bir kararla iptal edilmiştir (28). Bunun üzerine, Sağlık Bakanlığg tarafından 2016/6 sayılı yeni bir Genelge yayımlanarak uygulamaya konulmuştur (29). Buna göre, "kamu sağlığının korunması amacıyla kişisel sağlık verilerinin gizlilik, güvenlik, bütünlük ve mahremiyeti korunarak Sağlık.Net Online Sistemi ve bu sisteme bağlı olarak çalışarak ilgili kişilerin kendilerinin veya yetki verdikleri üçüncü kişilerin sağlık verilerine erişimini sağlayan Kişisel Sağlık Kaydı Sisteminin (e-Nabız) geliştirildiği”" bildirilmiştir. Söz konusu Genelge, 6698 sayılı Kanun'a atıfta bulunarak, Danıştay tarafından iptal edilen önceki Genelge'de mevcut normatif eksikliklerin giderildiği bir içerik kazanmıştır.

Yapılan diğer bir düzenleme ise Sağlık Bakanlı̆̆ tarafindan 21 Haziran 2019 tarihli ve 30808 sayılı Resmi Gazete'de yayımlanan "Kişisel Sağlık Verileri Hakkında Yönetmelik” olmuştur. Bu düzenleme ile 6698 sayılı Kanun aracılığıyla belirlenen hükümlerin Sağlık Bakanlığına bağlı merkez ve taşra teşkilatı birimlerine bağlı sağlık sunucularının uyması gereken usul ve esasların belirlenmesi amaçlanmıştır. 2016 tarihli eski Yönetmeliğin yürürlükten kaldırılmasına temel teşkil eden Kişisel Verileri Koruma Kurulu'nun görüşü alınmaması ve Kurul tarafından bu alana ilişkin yeterli önlemlerin belirlenmemiş olması gibi sorunlar, 2019 tarihli yeni Yönetmelik ile giderilerek 6698 sayılı Kanun normatif olarak desteklenmiştir (30).

Yirminci yüzyılın ortalarından itibaren, kişisel verilerin korunmasına yönelik uluslararası düzeyde gelişmeler yaşanmaya başlamıştır. Özellikle, Avrupa Birliği (AB) çatısı altında sürdürülen çalışmalar, üye devletlerin iç hukukuna doğrudan etki edebilecek yasal düzenlemelerin oluşmasına zemin hazırlamış ve ayrıca AİHM'nin kişisel verilerin korunmasına ilişkin verdiği hukuki kararlar bu çalışmaların şekillenmesine katkı sağlamıştır (18,22,31). Türkiye'nin iç hukuk sistemine yansıması ise bazı sözleşmeler ile gerçekleşmiştir. Kişisel verilerin korunması konusu, özel hayata ve aile hayatına saygı hakkı kapsamında bazı uluslararası anlaşmalarda yer bulmasına rağmen bundan farklı olarak, temel hak şeklinde düzenlendiği de olmuştur.

Kişisel verilerin $\mathrm{AB}$ üye ülkeler arasında ticari amaçlarla kullanımın yaygınlaşması neticesinde üye ülkeler arasında birlik sağlamak için Avrupa Komisyonu tarafından 24 Ekim 1995 tarihli ve “95/46/EC Sayılı Kişisel Verilerin İşlenmesi Ve Bu Tür Verilerin Serbest Dolaşımına Dair Bireylerin Korunmasına İlişkin Direktif” (95/46/EC sayılı Veri Koruma Direktifi) yayımlanmıştır. Bu Direktif ile "kişisel verilerin korunmasına ilişkin üye ülkelerin ulusal mevzuatları uyumlaştırılarak verilerin tüm AB ülkelerinde aynı düzeyde ve benzer ilkeler çerçevesinde korunması ve bu yolla verilerin söz konusu ülkelerde herhangi bir güvenlik riski bulunmaksızın serbest dolaşımını sağlanması" amaçlanmıştır (madde 2). Artan ekonomik faaliyetler içerisinde, teknolojinin gelişmesiyle birlikte veri kullanımının artması ve rolünün hızla değişmesi söz konusu Direktifin güncellenmesi ihtiyacını ortaya çıkarmıştır. Bu kapsamda, ABGVKT 14 Nisan 2016 tarihinde Avrupa Parlamentosu tarafından onaylanmıştır. Buna göre, 6698 sayılı Kanun’un Türkiye'de yürürlüğe giriş tarihi, aslında AB Veri Koruma Reformu kapsamında hazırlanan ABGVKT metninin Avrupa Parlamentosu'nda kabulünden kısa bir süre önce olmuştur. Bu nedenle, 6698 sayılı Kanunun oluşturulma sürecinde esas alınan uluslararası düzenlemenin, güncel olan 2016 tarihli ABGVKT değil, 95/46/EC sayılı Veri Koruma Direktifi'nin olduğu anlaşılmaktadır $(26,32)$.

Avrupa İnsan Hakları Sözleşmesine bakıldığında ise kişisel sağlık verilerinin korunmasına ve işlenmesine yönelik açık bir düzenleme bulunmamaktadır. Bu konuda AİHM kararları incelendiğinde, kişisel sağlığın korunması ve veri ihlalleri konularının Sözleşmenin "Özel ve Aile Hayatına Saygı Hakkı" kenar başlıklı 8. maddesi kapsamında değerlendirdiği görülmektedir. Mahkeme, kişisel sağlık verilerinin işlenmesi, toplanması ve saklanması işlemlerinin nasıl ve hangi amaç ile yapılacağının açık bir düzenleme ile belirtilmesi gerektiğinin yanı sıra kamu yararı ve ulusal güvenliğin temel amaç olma şartını aramıştır. Mahkeme'ye göre, buna yönelik yapılacak uygulamalarda amacın sadece kamu menfaati için olduğu açıklaması yeterli olmayıp, aynı zamanda bu işlem ile amacın nasıl birleştirildiğinin anlaşılır olması gerekmektedir (17).

Sonuç olarak değerlendirildiğinde, Türkiye'de idare tarafından düzenlenmek ve kontrol edilmek istenen kişisel sağlık verileri hakkında yeterli idari ve hukuki düzenlemelerin olmayışı nedeniyle, ayrıca yapısal bazı değişikliklerin öngörülmesi şartıyla çeşitli iptaller ve yürütmenin durdurulması kararları verilmiştir. Bu kapsamda, Türkiye'nin kişisel sağlık verileri de dahil olmak üzere, veri koruma konusu ile ilgili yasal düzenlemeleri 6698 sayılı Kanun ile kapsamlı olarak ele almaya başlamasının Avrupa Birliği üye ülkeleri ile karşılaştırıldığında daha geç olduğu söylenebilir (22).

\section{Kişisel Să̆lık Verilerine Yönelik Yargı Kararlarında İdarenin Yeri}

Bilgi toplumuna geçiş sürecinde gerekli olan temel hakların ve özgürlüklerin zarar görmemesi için idare tarafından uygulamaya konulan düzenlemeler yoluyla, kişisel verilerin korunması beraberinde idarenin yüklenmiş olduğu hukuki sorumluluğu da gündeme getirmiştir. İdare tarafından yapılan düzenlemeler yüksek mahkemeler tarafından yasal denetime tabi olduğundan, bu başlık altında öncelikle Danıştay ve Anayasa Mahkemesi tarafından kişisel sağlık verilerinin korunması konusunda idarenin hukuki sorumluluğuna yönelik verilen kararlar incelenecektir. Ayrıca Avrupa İnsan Hakları Mahkemesi tarafından verilen kararlar Türkiye Cumhuriyeti’nin iç hukukunda bağlayıcı niteliği olduğundan, "Özel ve Aile Hayatına Saygı Hakkı" kenar başlıklı 8. maddesi kapsamında verilen kararlar sağlıkta kişisel veri bağlamında açıklanacaktır.

Kişisel Sağlık Verileri Hakkında Yönetmelik (2019 tarihli) ile hassas veri niteliğindeki kişisel sağlık bilgilerinin korunmasına ve veri mahremiyetinin sağlanmasına yönelik düzenleme yapma yetkisi idare olarak Sağlık Bakanlığına tanınmıştır. Ayrıca, Danıştay’ın vermiş olduğu 2015 tarihli bir kararında, sağlıkla ilgili verilerin korunmasında idarenin bilgi güvenliği ve mahremiyeti yükümlülüğü altında olduğu açıkça belirtilmiştir (33). Söz konusu yükümlülüklerin nasıl yerine getirilmesi gerektiği ve kimleri kapsadığı 2019 tarihli Kişisel Sağlık Verileri Hakkında Yönetmelik ile belirlenmiştir. Buna göre, mahremiyet ve koruma yükümlülüğünü ihlal eden kişilerin kamu sağlık kuruluşunda bulunması ile özel sağlı kuruluşunda bulunması (özel hukuk gerçek veya tüzel kişisi) durumuna göre yapılacak olan hukuki işlemler ve yaptırımlar farklılık 
göstermektedir. İdarede görev yapan kamu görevlilerine yönelik Kişisel Verileri Koruma Kurulu'nun yapacağı bildirim üzerine disiplin işlemlerinin yapılabileceği, şayet 5237 sayılı Türk Ceza Kanunu 135-140. maddeler kapsamında, "kişisel verilerin hukuka aykırı olarak elde edilmesi, kaydedilmesi veya ifşa edilmesine yönelik suç oluşması durumunda bu fiili yapan gerçek kişilere" yönelik adli işlemlerin yapılacağı belirlenmiştir. Diğer yandan, ihlallerin özel hukuk kapsamında gerçek ve tüzel kişileri tarafından yapılması durumunda ayrıca kabahat bağlamında değerlendirildiği ve bazı idari para cezalarıyla yaptırım altına alındığ 6698 sayılı Kanun ile hüküm altına alınmıştır (madde 18). Dolayısıyla, kanun koyucu, idarenin sorumluluğuna doğrudan işaret etmek yerine idarede yer alan veri sorumlusu kamu görevlilerine yönelik yaptırımlar öngörmektedir.

Sağlık hizmeti sunmak amacıyla, aynı faaliyet çatısı altında yer alan birimlerin ya da gerçek veya tüzel kişilerin hastalarına ait olan tıbbi, sosyal, ekonomik ve demografik bilgileri kamusal ya da özel amaçlı nedenlerle birbirlerine aktarması kişisel sağlık verilerinin paylaşılması olarak tanımlanabilir. BMEKİÖ tarafından AB üye ülkeler arasında kişisel sağlık verilerinin tanı, tedavi, araştırma, hastalık önleme ve korunma ile birlikte ileri bilimsel araştırmalar için genom verilerinin paylaşılmasının önemli olduğu açıklanmıştır (34).

Türkiye'de ise bu verilerin paylaşılmasına yönelik Danıştay ve Anayasa Mahkemesi tarafindan verilen farklı kararlar mevcuttur. Bu kararlardan birisi de, sağlık hizmet sunucularının idare ile yapmış olduğu hizmet sözleşmesi nedeniyle, sağlık hizmeti sunduğu tüm kişilere ait kişisel sağlık verilerinin idareye gönderilmesini öngören 5510 sayılı Kanunun 78. maddesinin iptali için Danıştay’ın 2014 yılında Anayasa Mahkemesi'ne yapmış olduğu itiraz sonucunda vermiş olduğu gerekçeli karardır. Buna göre, "İdarenin, genel sağlık sigortasının işleyişi ile ilgili verilere ihtiyacı bulunduğu, söz konusu verilere sahip olunmadan, sağlık hizmetinden faydalanacak kişilerin tespiti; sağlık hizmeti sunucularına verdikleri hizmet karşılığında ödeme yapıllması; denetim ve kontrol görevinin yerine getirilmesi ve sosyal güvenlik politikalarının geliştirilmesine yönelik çalışmaların yapılmasının mümkün olmayacağı” vurgulanmıştır. Ayrıca, yüksek mahkeme idarenin yapmış olduğu bu uygulamayla kamu yararı amacıyla özel hayatın gizliliği hakkının sınırlandırıldığı vurgusuna rağmen, 78. maddesinin birinci fikrasının iptalinin reddine karar vermiştir (35). Bu sayede bütün sağlık hizmeti sunucularının (özel ya da kamu kaynaklı) elde ettikleri kişisel sağlık verilerinin idare ile paylaşılmamasına yönelik hukuki engel ortadan kalkmıştır. Bu karar ile idarede toplanan sağlık verilerinin işlenmesi ve korunması alanında idarenin hukuki sorumluluğu doğmuştur.

Danıştay'ın 2017 tarihli, kişisel sağlık verilerinin idare ile paylaşılması konusunda vermiş olduğu diğer bir kararda ise, eczacıların yapmış oldukları ilaç satışlarında hastalara ait reçete kayıt defterlerinin elektronik ortamda tutularak kişisel sağlık verilerinin kaydedildiği, bu verilerin mahremiyetini sağlamak için idare tarafından tespit edilen ölçütlere uygun bir şekilde merkezi sağlık veri sistemine aktarılması gerektiği iddia edilmesine rağmen, 6698 sayılı Kanun ile kurulan Kişisel Verileri Korumu Kurumu görüşünün alınması gerektiği belirtilmiştir (36).

Anayasa'nın 20.maddesi özel hayatın ve aile hayatının gizliliğine vurgu yaparak "herkesin kendisiyle ilgili kişisel verilerin korunmasını, düzeltilmesini veya silinmesini talep etme ve amaçları doğrultusunda kullanılıp kullanılmadığını öğrenme hakkını" da güvence altına almıştır. Bu kapsamda, Anayasa Mahkemesi vermiş olduğu çeşitli kararlarda kişisel veri kavramının sınırlarını oldukça geniş tutmuş olup, kişinin adı soyadı, vatandaşlık numarası, aile bilgileri, motorlu taşıt plakası, sosyal güvenlik numarası, sağlık bilgileri gibi bireyi dolaylı yoldan veya doğrudan belirlenebilir kılan tüm verileri bu kavram altında değerlendirmiştir (37). Bununla ilgili Anayasa Mahkemesi’nin bir kararına göre, hatalı cerrahi gögüs operasyonu yapan doktora karşı açılan davada, mağdur olan hastanın dosyaya delil olarak sunduğu göğüs bölgesi fotoğraflarının mahrem nitelikte olması nedeniyle, bu fotoğraflara yönelik gizlilik kararının ilk derece mahkeme tarafından verilmemesinin hak ihlali yarattı̆̆ı sonucuna varılmıştır (38).

Bir eğitim ve araştırma hastane idaresi tarafından çalışanlarının mesai takibi amacıyla parmak izi tarama sistemi kullanılarak özel hayatın gizliliği ilkesinin ihlal edilmesine yönelik Danıştay İdari Dava Daireleri Genel Kurulu'nun vermiş olduğu bir karara göre (39); söz konusu uygulama ile "özel hayatın gizliliği ilkesi kapsamında bulunması karşısında uygulamanın sınırlarını, usul ve esaslarını gösteren bir yasal dayanağının bulunmaması, toplanan verilerin ileride başka bir şekilde kullanılamayacağına dair bir güvencenin mevcut olmaması göz önüne alındığında, temel haklar ve anayasal ilkeler ile birlikte uluslararası sözleşme kuralları ile bağdaşmayan dava konusu işlemde hukuka uyarlık bulunmadığı sonucuna varılmıştır.” Bu karar neticesinde, Danıştay, çalışanlarının parmak izi alınması gibi temel hak ve hürriyetler açısından önem taşıyan biyometrik (dirimölçümsel) verilerin işlenmesi ve korunmasını konusunda hassasiyetle durarak, idarenin personel yönetimine yönelik böylesi bir işlem gerçekleştiremeyeceğine karar vermiştir.

AİHS kapsamında, kişisel sağlık verilerine ilişkin olarak özel bir düzenleme bulunmamasına rağmen, AİHM içtihatları ile kişisel sağlık verilerinin, özel yaşama ve aile hayatına saygı hakkı başlıklı 8. maddesine göre incelendiği görülmektedir. AİHM tarafından verilen bazı kararlarda, kişisel verilerin korunması hakkı kapsamında değerlendirilen alanlarda (kişisel sağlık verilerine yetkisiz erişim, bu verilerin gereğinden daha fazla süre veritabanlarında muhafaza edilmesi gibi) özel hayatın gizliliği hakkına yönelik esaslara göre değerlendirme yapılmıştır (40). AİHS madde 46 açısından, AİHM kararları Türkiye hukuk sistemini bağlayıcı olduğundan, üye devletlere yönelik kişisel sağlık verilerinin korunması konusunda verilen kararlar idare hukuku kapsamında ele alınacaktır.

I. v. Finlandiya adlı karara konu olan olayda, HIV (Human Immune Virus) taşıyan hastanın kişisel sağlık verilerine hasta ile ilgisi olmayan diğer hastane çalışanlarının da erişimine açık tutulmasında hastane idaresinin hukuki sorumluluğuna değinilmiştir. Bu kapsamda, ülke mevzuatında kişisel verilerin açıklanması nedeniyle oluşabilecek olağan maddi ve manevi zararların tazmin edilmesine ilişkin olarak AİHS madde 8 kapsamında idare tarafindan yeterli güvence sağlanamadığ ve devletin kişisel verilerin korunmasındaki pozitif yükümlülüğü sağlayamaması nedeniyle, AİHS madde 8'in ihlal edildiğine hükmedilmiştir. Tıbbi kişisel verilerin önemine vurgu yapan bu kararda, yalnızca koruyucu yasal düzenlemelerin yapılması yeterli bulunmamış, kişisel sağlık verilerinin korunmasında idare tarafından alınması gereken ilave güvenlik tedbirlerinin de önemine değinilmiştir (24). 
AİHM tarafından verilen, 27.08.1997 tarihli bir başka karar ise "kürtaj hakkında bilgi içeren tıbbi kayıtların bir klinik tarafından sosyal güvenlik kurumuna iletilmesi” ile ilgilidir. Buna göre, M.S. v. İsveç adlı ve 20837/92 başvuru numaralı kararda, mahkeme, hasta hakkındaki kişisel sağlık verilerinin klinik tarafından sosyal güvenlik kurumu ile paylaşılmasının ülkedeki kamu düzeninin korunması yönündeki meşru amaç ile orantılı olduğunu değerlendirerek Sözleşmenin 8. maddesinin ihlal edilmediği sonucuna varmıştır (41). Mahkeme bu karara göre, kişisel sağlık verilerinin başka bir kamu kurumu ile paylaşılmasında öncelikli olarak kamu menfaatini aramış ve bunun için şartların oluşup oluşmadığına bakmıştır. Sonuç olarak, tıbbi verilerin idare ile paylaşılmasının demokratik bir toplumda izlenen amaçlarla orantılı olduğu kararı verilmiştir.

AİHM'nin önüne gelen davalardan bir diğeri ise kişisel sağlık verilerinin, bireyin açık rızası alınmadan idare tarafından kullanılması konusundadır. Buna göre, L.H. v. Letonya adlı davada (42), Letonya' da bir kamu idaresi tarafından tıbbi verilerin toplanması sırasında bu verilere yönelik amaç, konu ve süre yönünden hiçbir şekilde bir sınırlama yapılmamış olması nedeniyle, Sözleşme'nin 8.maddesinin ihlal edildiğine karar verilmiştir. Ayrıca bu karar ile birlikte mahkeme, bireylerin sahip olduğu özel hayata saygı hakkı konusunda tıbbi verilerin korunmasının önemi hatırlatılmıştır.

Genel olarak, AİHM tarafından bu kararlar incelendiğinde; hassas veri niteliğinde olan kişisel sağlık verilerinin, AİHS madde 8 kapsamında koruma altına alındığı görülmektedir. Mahkeme, gündemine gelen olaylarda, kanunla yapılacak açık bir düzenleme ile hassas verilerin nasıl, hangi amaçla ve verilerin toplanacağı yöntemin belirtilmesi gerektiği üzerinde önemle durmuştur. Bunun yanında, yapılan uygulamalarda açık bir şekilde kamu güvenliği ve kamu yararının temel amaç olma şartını da aramıştır (17). Bu nedenle, idare tarafından yapılacak uygulamalarda, sadece kamu yararı ilkesi ile hareket etmek Mahkeme tarafından yeterli görülmemekte, aynı zamanda yapılan işlem ile amacın nasıl birleştirildiğinin açıkça izah edilmesi gerekmektedir.

\section{İdarenin Kişisel Săğlk Verilerinden Kaynaklanan Hukuki Sorumluluğu}

İdarenin kamu hukukundan kaynaklanan sorumluluğunun yerine getirilmemesi sonucu hizmet kusuru ortaya çıkmaktadır. Kusur, kamu hizmetlerindeki faaliyetinden ya da kuruluşundan ortaya çıkan ve öznel nitelikli olmayan eksiklik veya bozukluk olarak tanımlanabilir. Hizmet kusuru ise idarenin yerine getirdiği kamu hizmetlerinin işleyişinde bulunan ve ilgili kamu görevlisinin denetim ve gözetim görevini yerine getirememesindeki anonim ve nesnel nitelikteki kusuru olarak tanımlanmaktadır (43). Diğer bir anlatımla, kamu hizmeti kötü ya da eksik işletilmekte veya bu işleyişin olması gereken hizmet gerekleriyle ilişkilendirilemeyecek bir özellik taşıması durumunda idarenin sorumluluğunu doğuran bir hizmet kusurunun var olduğu anlaşılır (44). Söz konusu bu hizmet kusurunun idarenin sunduğu sağlık hizmetinde yer alması ise sağlık hizmetlerinde hizmet kusurunu ifade etmektedir.

Genel olarak, hizmet kusuru, mevcut bir kamu hizmetinin işleyişinde meydana gelen bozukluk ve aksaklıkları ifade eder (17). Hizmet kusuru, ifayı yerine getiren kamu personelinin tutum ve davranışına atfedilemeyen objektif kusurdur (44). Ancak, bir kusur sağlık hizmeti sunumunda görevli kamu çalışanının göreviyle alakası olmayan ve görevinden bağımsız olarak görev faaliyeti esnasında gerçekleşmesiyle oluşan ve kişisel sorumluluğuna neden olan kusura ise salt kişisel kusur denir. Bu durumda, ilgili sağlık çalışanı haksız fiil nedeniyle sorumlu olur ve özel hukuk kurallarına göre adli mahkemelerde yargılanabilir (43).

İdarenin hizmet kusuruna dayanan sorumluluğu asli bir sorumluluktur (21). Ayrıca idare, kamu personelinin kusuru nedeniyle hizmet kusurunun meydana geldiğini iddia ederek hukuki sorumluluktan kurtulamaz. Ancak kamu çalışanının bulunduğu görev ve yetkilerin sağladığı imkânlardan yararlanarak gerçekleştirdiği suç niteliğindeki eylemler ise görev kusuru olarak kabul edilmektedir. Hizmet ve kişisel kusurun birbirine çok yakın olmasından dolayı, kamu çalışanının eylemleri nedeniyle idare asli sorumlu sayılmaktadır. İdare bunu çalışanına rücu edebilecektir. İdarenin kusuru sonucu olaşan maddi ya da manevi zararın varlığı halinde ise idarenin tazmin borcu meydana gelmektedir. Bunun için idari yargıya özgü bir dava türü olan tam yargı davası aracılığıyla idarenin hukuki sorumluluğunun bulunup bulunmadığı tespit edilir. Tam yargı davası aracılığıyla idarenin ihlal ettiği ya da yerine getirmediği bir hakkı yerine getirmesi veya bunun sonucunda bireyin uğradığı zararın giderilmesi amaçlanmaktadır (44).

Sağlık hizmetleri, tıbbi ve teknik bilgiyi gerektiren ve doğası gereği faaliyetlerinde hayati risk taşıyan hizmetler arasındadır. Bu nedenle, idari bir faaliyet sonucu bireyin zarara uğraması durumunda, zararın ortaya çıkmasında idarenin hizmet kusurunun varlığ idarenin sağlık hizmetleri sunumunda sorumluluğunda olan başlıca zararlar, bedensel bütünlüğün bozulması sonucu bedensel zararları, ölüme bağlı meydana gelen maddi zararları, mala ilişkin zararları (vücuda protez takılması gibi), bireyin sahip olduğu kişilik değerinde ve şahıs varlığında meydana gelen her türlü manevi zararları kapsamaktadır (44). Dolayısıyla, idare tarafından hassas veri niteliğindeki kişisel sağlık verilerinin hukuka aykırı bir biçimde işlenmesi, depolanması ve aktarılması nedeniyle tam yargı davası ile birey, uğradığı maddi zararlar ile birlikte ağır kişilik hakkı ihlali durumunda manevi zararları da idareden tazminat yoluyla isteyebilmektedir.

İdarenin yerine getirmesi gerekli olan en önemli görevlerden birisi de kişisel verilerin korunması ve güvenli bir şekilde transferinin gerçekleştirilmesidir. Anayasa Mahkemesi 2008 tarihinde vermiş olduğu bir kararda bilgi toplama, saklama, işleme ve değiştirme tekelinin idareye ait olduğunu vurgulamıştır (45). Benzer bir şekilde hassas verilerin güvenli bir şekilde muhafaza edilmesinin önemine yönelik Danıştay tarafından verilen bir karara göre, "hassas veriler ile bireyin temel hak ve özgürlükleri arasında yakın bir ilişki bulunması nedeniyle de bu nitelikteki verilerin bireyin diğer kişisel verilerinden daha etkin ve özel koruma altına alınması gerekmektedir"(46). İdare, sosyal devlet olmanın gereklerini yerine getirebilmek, halkın huzur ve refahını sağlayabilmek amacıyla vatandaşlarının doğumundan ölümlerine kadar verilerini toplamakta ve arşivlemektedir. Dolayısıyla, idare hukukunda idarenin kişisel sağlık verilerinden kaynaklanan ve yerine getirilmediği takdirde hizmet kusuru niteliğinde olan sorumlulukları bulunmaktadır. Ayrıca kişisel sağık verilerinin korunması hakkına ilişkin idare tarafından yasal bir dayanak olmaksızın yapılacak düzenleme veya bu hakkın sınırlandırılması hukuka aykırı olacaktır (21). 
Sağlık hizmetlerinden yararlanan bireylerin kişisel sağlık verileri ile ilgili kayıtlarının eksik tutulması, hatalı tutulması ya da yapılan tedavilerin kayıt altına alınmaması, Danıştay tarafından hizmetin kusurlu işletilmesi için yeterli görülmektedir. Danıştay’ın vermiş olduğu bir kararda, hastaya ait röntgen grafilerinin hastanın dosyasında muhafaza edilmediği için mahkemeye ibraz edilememesi sonucu idarenin hizmet kusuru olduğu ifade edilmiş, tıbbi verileri kaybolan hastanın yaşanan bu belirsizlik nedeniyle üzüntü duyduğunu, bu nedenle uğranılan manevi zararın tazmin edilmesi gerektiğine hükmedilmiştir (47). Danıştay tarafından verilen başka bir kararda ise hasta ile ilgili tutulan kişisel sağlık verilerinin, hasta için yapılan tedavileri ve tedavi sonrası oluşabilecek zararlı sonucun sebeplerini anlamasına imkân sağlayacak olan tıbbi kayıtların eksik, hatalı ya da hiç tutulmaması nedeniyle hasta hiçbir zaman rahatsızlı̆̆ının nedenini öğrenemeyeceği, bu nedenle sağlık verilerinin eksik tutulmasının hastanın doğruyu öğrenme hakkına engel olunacağı vurgulanmıştır (17).

Diğer yandan, dünya genelinde birçok ülkeye yayılan COVID-19 gibi bulaşıcı hastalıklardan korunmak ve yayılımını önlemek amacıyla idare tarafından bazı sosyal ve idari tedbirler alınmaktadır. Bu gibi salgın hastalıklarda toplum sağlığının korunması için, bulaşıcı hastalığı taşıyan veya taşıma riski bulunan kişiler ile temas kuranların tespit edilmesi amacıyla idare tarafından yetkili kurum ve kuruluşlarca ilgili kişilerin iletişim bilgileri, daha öncesinde bulunduğu mekan ve şehirler, son zamanlarda temas edilen kişiler gibi hassas veri niteliğinde olan bilgilere ihtiyaç duyulabilmektedir. İnsan Hakları Biyotıp Sözleşmesi (maddeler 5-10), Anayasa (m.20) ve 6698 sayılı Kanun (maddeler 5-9) esaslarınca kişisel verilerin güvenliği gözetilmiş olup, söz konusu bu tür veriler özel nitelikte veri olmasından dolayı, yetkili kurum ve kuruluşlarca paylaşılmasında temel prensip kişinin rızası ile verilmesidir. Şayet, hastalığın yasal düzenlemelerle belirlenmiş ihbarı zorunlu bir hastalık sınıfında olması durumunda, 1593 kanun numaralı Umumi Hıfzıssıhha Kanunu (maddeler 29-56) gereği yetkili kişiler tarafından bildirimi zorunludur. Salgın durumlarında, idare tarafından, rıza ile elde edilen kişisel sağlık verilerinin, 6698 sayılı Kanun (madde 28) kapsamında kamu sağlığı bakımından işlenmesi mümkündür. Ancak bu verilerin, ilgili olmayan üçüncü kişilerce paylaşılması ya da ele geçirilmesi durumunda, ilgili veri sahipleri bakımından zararlar ortaya çıkabileceği dikkate alındığında, idare kişisel sağlık verilerinin güvenliği için yeterli seviyede her türlü teknik ve idari tedbirlerin alınmasından sorumlu olabilecektir. Ayrıca 6698 sayılı Kanun (madde 7) gereği, idarenin elde ettiği hassas verilerin işlenmesini mümkün kılan şartların sona ermesi durumunda bu verilerin anonimleştirilmesi veya silinmesi gerekmektedir.

\section{İdare Hukuku Çerçevesinde Kişisel Verileri Koruma Kurumu}

Kişisel verilerin korunmasına ilişkin usul ve esasları belirmeye yönelik çerçeve bir düzenleme, "6698 sayılı Kişisel Verilerin Korunması Kanunu” başlı̆̆ı ile 07.04.2016 tarihli ve 29677 sayılı Resmi Gazete’de yayımlanarak yürürlüğe girmiştir. Söz konusu Kanun ile belirlenen görev ve usulleri yerine getirmek için mali ve idari özerkliği bulunan, kamu tüzel kişiliğine haiz olan "Kişisel Verileri Koruma Kurumu” kurulmuştur. Kurumun başlıca görevleri arasında "ulusal ve uluslararası alanda uygulama ve mevzuattaki gelişmeleri takip ederek araştırma ve inceleme faaliyetlerinde bulunma ile birlikte ulusal-uluslararası kurum ve kuruluşlarla işbirliği yapma ve ihtiyaç duyulan hususlarda önerilerde bulunması" yer almaktadır (madde 20-22).

Söz konusu Kurum, kişisel verilerin korunması ve ihlallerin önlenmesine yönelik tebliğ, yönetmelik gibi işlemlerle düzenleyici yetkisini kullanırken; 6698 sayılı Kanunda öngörülen idari yaptırımları ve tedbirleri uygulamaktadır. Kurulun 2018 tarihinde vermiş olduğu bir kararda, ilgili idare tarafından, başta sağlık hizmetleri olmak üzere diğer hizmetlerin sağlandığ 1 "kamu ve özel sektör kurumlarının banko/gişe/masa gibi hizmet alanlarında yetkisiz kişilerin yer almasını önlemek ve hizmet alım sırasında bireylerin birbirlerine ait kişisel verileri görmesini, duymasını veya elde etmesini engelleyecek idari ve teknik önlemlerin alınması gerektiği” bildirilmiştir (48). Bu karar ile sadece gerçek kişiler ile özel hukuk tüzel kişilerine değil aynı zamanda kamu hizmeti sağlayan idareye de önleyici ve koruyucu tedbirlerin sağlanmasına yönelik yükümlülük vermiştir. Karara göre; kamu veya özel sağlık kuruluşlarında hastane idaresi tarafından hastaların birbirlerinin adı ve soyadı, kimlik numarası gibi kişisel sağlık verilerini açıkça görmesini ve elde etmesini önlemek, aynı zamanda muayene ve tedavi faaliyeti sırasında sağlık profesyonelleri tarafından hastaların kişisel veri niteliğindeki bilgilerinin diğer üçüncü şahısların elde etmesinin önüne geçmek için idari ve teknik tedbirlerin alınmasının hukuki açıdan çok önemli olduğu anlaşılmaktadır. Özellikle, hastanelerde elektronik hasta çağrı sistemlerinde hastaların anonimleştirilmemiş ad soyad veya kimlik numarası gibi bilgilerin diğer hastalar tarafından rahatlıkla elde edilebilecek şekilde yer alması ya da kişiye ait tıbbi sonucun (röntgen, laboratuvar vb.) üçüncü şahıslar tarafından rahatlıkla görülmesi sonucu buradaki bilgilerin elde edilebilmesi gibi olası ihlallerde idarenin yanında ilgili veri sorumluların da hukuki sorumlulukları 6698 sayılı Kanun çerçevesinde gündeme gelecektir.

Kurul tarafından verilen düzenleyici kararların ihlali halinde yapılacak olan işlem, ihlali gerçekleştiren kişi ya da kuruma göre farklılık göstermektedir. Buna göre, ihlalin özel hukuk tüzel kişileri ile veri sorumlusu olan gerçek kişiler tarafından gerçekleştirilmesi idari para cezasını gerektirirken, bu ihlallerin her türlü kamu kurumlarında veya bu nitelikteki meslek kuruluşları çatısı altında görev yapanlar hakkında ise disiplin hükümlerine göre işlem yapılacağı, 6698 sayılı Kanunun 18. maddesinde açıkça yer almıştır. Ayrıca, idarenin kişisel sağlık verileri de dahil hassas verilerin işlenmesine ilişkin aykırılık gerçekleştirmesi halinde, mağdur olan ilgili kişi, idarenin gerçekleştirdiği bu tür eylem ve işlemleri nedeniyle idareye karşı tam yargı davası açabilecektir.

Kişisel veriler temel hak ve özgürlüklerin korunması kapsamında değerlendirildiğinden, ulusal ve uluslararası düzenlemelerde önemli bir yer tutmaktadır. Özellikle kişisel sağlık verilerinin kim tarafından nasıl işlenmesi gerektiği, ne kadar süre ve neden gizli tutulması gerektiği, yetkisiz paylaşım konusunda idarenin alması gereken tedbirler çeşitli yüksek mahkeme kararlarında açıkça belirtilmiştir.

\section{Hemşirelik Hizmetleri Bakımından Kişisel Sağlık Verileri}

Hemşirelik hizmetleri bünyesinde barındırdığı profesyonel bilgi gücü, yetişmiş personel sayısı ve bunların üstlendiği sorumluluklar bağlamında hastane ve sağlık kuruluşlarının yönetiminde önemli bir yere sahiptir. Koruyucu, tedavi ve rehabilite edici sağlık hizmetlerinin her aşamasında hastalarla iletişim ve etkileşim halinde olan hemşireler, hasta mahremiyeti ve kişisel 
sağlık verilerinin korunması konularında da cezai ve hukuki yönden sorumlu olabilirler. Bu sorumluluklar hasta ve yakınlarına ait tıbbi kayıtların 6698 sayılı Kanunda öngörülen amaçlar dışında elde edilmesi, işlenmesi ve 3.şahıslarla paylaşılması gibi eylemlerden kaynaklanmaktadır. KVKK veri ihlallerinde sorumluluğun gerçek veya tüzel kişide olabileceğini açıkça belirtmiştir (Madde 17-18). TCK 137.maddesi ise bu sorumluluğun kamu görevlisi tarafından görevinin verdiği yetki kötüye kullanmak ve belli bir mesleğin icrasının sağladığı kolaylıktan yararlanmak suretiyle meydana gelmesini nitelikli hallerden sayarak cezai yaptırımın arttırılmasını öngörmüştür. Bu nedenle, hemşirelik hizmetlerinin yerine getirilmesi için idare bünyesinde görev yapan veyahut özel sağlık hizmeti sunan kurumlarda bulunan hemşirelerin hasta ve yakınlarına ait kişisel sağlık verilerini hukuka aykırı ele geçirme ve paylaşma konularında, gerek mesleki statülerinden gerekse bulundukları idari pozisyonlarından (klinik başhemşireliği, hemşirelik hizmetleri müdürü vb.) kaynaklı sorumluluğu doğabilecektir.

\section{Sonuç}

Teknolojinin gelişmesiyle birlikte kişisel verilerin hızla işlenmesi ve elde edilmesi beraberinde özel hayat ve mahremiyet kapsamında bazı hukuki sorumlulukların doğmasına da neden olmaktadır. Özellikle hassas veri niteliğinde olan kişisel sağlık verilerinin en çok işlendiği yer sağlık hizmetleridir. Söz konusu verilerin gerektiği gibi tutulmaması, hukuka aykırı işlenmesi ya da izinsiz üçüncü kişiler ile paylaşılması sadece özel sağlı kurumları açısından özel hukuk kapsamında değil aynı zamanda kamu sağlık kurumları açısından kamu hukuku kapsamında idarenin sorumluluğunu doğuracak niteliktedir. Bu durum, idarenin bireylerin kişisel sağlık verilerini koruma yükümlülüğünden kaynaklanmaktadır.

İdare tarafından kişisel sağlık verilerinin işlenmesi sırasında, kanuna aykırılık sonucu idarenin hizmet kusuru doğabilir. $\mathrm{Bu}$ nedenle, bireyler maddi veya manevi zarara uğrayabilir. Anayasa ve 6698 sayılı Kanun tarafından güvence altına alınan kişisel sağlık verilerinin ihlali nedeniyle idareye karşı açılan davalar, her somut olayın gereklerine göre farklı olarak idari yargı tarafından değerlendirilecektir. Buna yönelik, Danıştay ve Anayasa Mahkemesi tarafından verilmiş kişisel verilerin gizliliğinin korunmasına yönelik kararların, uluslararası hukuki düzenlemelerde yer aldığı gibi temel hak ve özgürlükleri koruyucu bir eksen etrafinda verildiği görülmektedir.

Dünya genelinde elektronik veri kayıt ve depolama imkânlarının giderek daha da kolaylaşması karşısında, sağlık hizmeti sunan idarelerin bu duruma kayıtsız kalması mümkün değildir. Bu nedenle, oluşabilecek her türlü veri ihlallerine karşı sağlık profesyonellerine yönelik veri güvenliği hakkında eğitimler verilmelidir. Hastane idaresi tarafından yasal mevzuatlar çerçevesinde veri sorumlusu kişiler belirlenmeli ve bu kişilere yönelik ayrıca hizmet içi eğitimler yapılmalıdır.

Herkesin rahatlıkla görüp, duyabileceği poliklinik ve muayene gibi hizmetlerde hastalara ait bilgilerin korunmasına, gerekirse anonimleştirilmesine idare tarafından dikkat edilmelidir. Örneğin, çeşitli kamu hastanelerinde elektronik hasta çağrı levhalarında hastaların adı soyadı veya kimlik numarası bilgileri ile değil, alacakları sıra numarası ile muayene/tedavi hizmeti almaları mümkün olabilir.

Hastane veri kayıt sistemlerinde yer alan hastalara ait bilgilerin özel olarak korunması gereken veri niteliğinde olmasından dolayı, ilgili sağlık çalışanının hastanın ilgili verilerine yetki dahilinde erişimi sağlanmalıdır. Bu sayede üçüncü şahıs niteliğinde olan diğer sağlık profesyonelleri tarafından kişisel sağlık verilerinin keyfi biçimde işlenmesi önüne geçilebilir.

İdare aracılığıyla sağlık hizmeti sunulan kurum ve kuruluşlarda, sadece 6698 sayılı Kanun kapsamında kurulan Kişisel Veri Koruma Kurulu tarafından alınan kararların, ulusal ve uluslararası düzenlemelerde ortaya çıkan veri güvenliğine yönelik güncel gelişmelerin takip ve uyumunu sağlamak amacıyla değil, aynı zamanda sağlık idaresi içinde yer alan birimlerin veri toplama, işleme ve saklama süreçlerinin yakından denetimini sağlamak amacıyla veri güvenliği kontrol birimleri kurulmalıdır.

\section{Bilgilendirme}

Bu derleme çalışması sırasında kamu, ticari veya kar amacı gütmeyen sektörlerdeki fon kuruluşlarından herhangi bir özel hibe alınmamıştır.

$\mathrm{Bu}$ derlemede yer alan bütün başlıklar ve bunların araştırılması ile birlikte yazılması sürecinde başkaca bir kişi veya yazarın katkısı olmamıştır.

Bu çalışma Helsinki Bildirgesi'ne uygun bir biçimde, yayın etiği esaslarına uyularak hazırlanmıştır.

Yazar tarafından herhangi bir teşekkür belirtilmemiştir.

Yazar tarafından herhangi bir çıkar çatışmasının olmadığı bildirilmiştir.

\section{Kaynaklar}

1. Brown JS, Duguid P. Enformasyonun Sosyal Yaşamı. Çeviri: Bingöl Ç. Türk Henkel Dergisi Yayınları; 2001.

2. Ojha AC, Pani SK. Data science and big data analytics. In: Satpathy S, Mohanty SN, Big Data Analytics And Computing For Digital Forensic Investigations. CRC Press Publishing, 2020: 40-150.

3. Cui Y, Kara S, Chan KC. Manufacturing big data ecosystem: A systematic literature review. Robot Comput Integr Manuf. 2020;62 (1), 101861.

4. He J, Baxter SL, Xu J, Xu J, Zhou X, Zhang K. The practical implementation of artificial intelligence technologies in medicine. Nat Med. 2019;25(1):30-6.

5. Regulation (EU) $2016 / 679$ of the european parliament and of the council. https://eur-lex.europa.eu/legalcontent/EN/TXT/HTML/?uri=CELEX:32016R0679\&from=EN. Erişim Tarihi: 10 Mayıs 2020.

6. Madde ve gerekçesi ile kişisel verilerin korunması kanunu. Ankara: KVKK Yayınları; 2019. https://www.kvkk.gov.tr/Icerik/5388/Madde-ve-Gerekcesi-ile-Kisisel-Verilerin-Korunmasi-Kanunu-Bilgi-Notu-ve-

Kisisel-Verilerin-Korunmasina-Iliskin-Terimler-Sozlugu. Erişim Tarihi: 10 Mayıs 2020.

7. Truong NB, Sun K, Lee GM, Guo Y. GDPR-Compliant personal data management: a blockchain-based solution. IEEE Transactions on Information Forensics and Security. 2020;15(October):1746-61.

8. Anayasa Mahkemesi'nin 2014/1970 başvuru numaralı, 22.11.2017 tarihli kararı. Dokuz Eylül Üniversitesi Hemşirelik Fakültesi Elektronik Dergisi ～https://dergipark.org.tr/tr/pub/deuhfed 
http://www.kararlaryeni.anayasa.gov.tr/Content/pdfkarar/2014-1970.pdf. Erişim Tarihi. 20 Mayıs 2020.

9. Anayasa Mahkemesi'nin 9/4/2014 tarihli ve E: 2013/122, K: 2014/74 sayılı kararı http://www.resmigazete.gov.tr/eskiler/2014/07/20140726-15.pdf. Erişim Tarihi. 20 Mayıs 2020.

10. Kişisel sağlık verileri hakkında yönetmelik. https://www.resmigazete.gov.tr/eskiler/2019/06/20190621-3.htm. Erişim Tarihi. 20 Mayis 2020.

11. Bietz MJ, Bloss CS, Calvert S, Godino JG, Gregory J, Claffey MP, et al. Opportunities and challenges in the use of personal health data for health research. J Am Med Inform Assoc. 2016; 23 (e1), 42-48.

12. Karampela M, Ouhbi S, Isomursu M. Personal health data: a systematic mapping study. Int J Med Inform. 2018; 118:8698.

13. Öztek Z. Sağlık kavramı ve sağlık hizmetleri. Yeni Türkiye Dergisi. 2001; Sağlık özel sayısı (39):295.

14. Öztek Z. Halk Sağlı̆̆ı Bakışıyla Sağlık Hizmetleri: Kavramlar-İlkeler-Politikalar. 1.Basım. İstanbul: Maltepe Üniversitesi Tıp Fakültesi. 2019: 22-50.

15. World Health Organization (WHO). Health services https://www.who.int/topics/health_services/en/. Erişim Tarihi: 21 Mayıs 2020

16. Dülger MV. Kişisel sağlık verilerine ilişkin ceza ve idare hukuku normları. Kişisel sağlık verileri II.Ulusal Kongresi (3-4 Haziran 2017). Türk Tabipler Birliği Yayınları. 2017: 8-52. https://www.ttb.org.tr/kutuphane/ksv_2017.pdf. Erişim Tarihi: 18 May1s 2020

17. Altundiş $\mathrm{M}$. Tıbbi kişisel verilerin tutulması ve korunması yükümlülüğü ve idarenin bu yükümlülüğünü yerine getirmemesinden doğan sorumluluğu. Türkiye Adalet Akademisi Dergisi. 2016;7(28):313-51.

18. Carey P. Data protection: a practical guide to UK and EU law. Fifth edition. Oxford University Press. 2018: 3-10.

19. “Özel nitelikli kişisel verilerin işlenmesinde veri sorumlularınca alınması gereken yeterli önlemler” ile ilgili Kişisel Verileri Koruma Kurulu'nun 31/01/2018 tarihli ve 2018/10 sayılı kararı https:/www.kvkk.gov.tr/Icerik/4110/2018-10. Erişim Tarihi: 26 Mayıs 2020.

20. Kaya C. Avrupa birliği veri koruma direktifi ekseninde hassas (kişisel) veriler ve işlenmesi. İstanbul Üniversitesi Hukuk Fakültesi Mecmuası. 2011;69(1-2):317-34.

21. Akgül A. Avrupa insan hakları mahkemesi kararlarında kişisel verilerin korunması hakkı. Terazi Hukuk Dergisi. 2014;9(92):72-81.

22. Bart Custers, Alan M.Sears FD. EU Personal Data Protection İn Policy And Practice. First edition. Netherlands: Asser Press, Springer. 2019: 1-192.

23. Winter JS, Davidson E. Big data governance of personal health information and challenges to contextual integrity. Inf Soc. 2019: 35(1):1-10.

24. Atak S. Avrupa konseyinin kişisel veriler açısından sağladığı temel güvenceler. Türkiye Barolar Birliği Dergisi. 2010;87:90-120.

25. Danıştay 15.Dairesi'nin E.2016/10488 YD. T.6.7.2017 sayılı kararı. Lexpera İçtihat Bankası. https://www.lexpera.com.tr/ictihat/danistay/15-d-e-2016-10488-k-yd-t-6-7-2017. Erişim Tarihi: 22 May1s 2020.

26. Henkoğlu T. Veri koruma kanununun getirdikleri. Journal of Current Research on Social Sciences. 2017;7(2):241-50.

27. Danıştay 15.Dairesi'nin 17.01.2018 tarih ve E.2017/2258 sayılı kararı. http://www.ttb.org.tr/userfiles/files/D_15 YD HK_karar.pdf. Erişim Tarihi: 22 Mayıs 2020.

28. Danıştay 15.Dairesi'nin E.2015/3035 ve K.2017/6611 sayılı kararı. https://www.lexpera.com.tr/ictihat/danistay/15-d-e2015-3035-k-2017-6611-t-14-11-2017. Erişim Tarihi: 20 Mayıs 2020.

29. Sağlık Bakanlığı'nın 2016/6 numaralı ve 26 Nisan 2016 tarihli Genelgesi https://kisiselveri.saglik.gov.tr/TR,56190/20166sayili-genelge.html. Erişim Tarihi: 23 Mayıs 2020.

30. Danıştay 15.Dairesi'nin 06.07.2017 tarih ve E.2016/10500 sayılı ve 26.06.2018 tarih ve E.2018/844 sayılı kararları. http://www.ttb.org.tr/userfiles/files/ksv-yd.pdf. Erişim Tarihi: 19 Mayıs 2020.

31. Özdemir H. Elektronik Haberleşme Alanında Kişisel Verilerin Özel Hukuk Hükümlerine Göre Korunması. Seçkin Yayınevi. 2009: 22-80.

32. Akıncı AN. Avrupa birliği genel veri koruma tüzüğ̈̈nün getirdiği yenilikler ve türk hukuku bakımından değerlendirilmesi. Ankara; 2017. http://www.sbb.gov.tr/wpcontent/uploads/2018/11/AvrupaBirliğiGenelVeriKorumaTüzügününGetirdiğiYeniliklerveTürkHukukuBakımındanDeğerlendirilmesi.pdf. Erişim Tarihi: 02 Haziran 2020.

33. Danıştay 15.Dairesi'nin 06/07/2015 tarih ve E:2015/3602 sayılı kararı http://www.ttb.org.tr/userfiles/files/evde-saglikdanistay-karar-son.pdf. Erişim Tarihi: 01 Haziran 2020.

34. OECD. Health in the 21st century: putting data to work for stronger health systems. OECD Publishing, Paris.; 2019. 1-261 p. (OECD Health Policy Studies). Available from: https://www.oecd-ilibrary.org/social-issues-migration-health/health-inthe-21st-century_e3b23f8e-en. Erișim Tarihi: 30 Mayıs 2020.

35. Anayasa Mahkemesi'nin 25.12.2014 tarihli, $\quad$ E.2014/74, $\quad$ K.2014/201 say1l http://kararlaryeni.anayasa.gov.tr/Karar/Content/0e1371e0-2293-43f9-9201-

711f645e48b7?excludeGerekce=False\&wordsOnly=False. Erişim Tarihi: 28 Mayıs 2020.

36. Danıştay 15.Dairesi'nin E.2016/10488, YD.T.6.7.2017 sayılı kararı https://www.lexpera.com.tr/ictihat/danistay/15-d-e2016-10488-k-yd-t-6-7-2017. Erişim Tarihi: 18 Mayıs 2020.

37. Anayasa Mahkemesi'nin 28.09.2017 tarihli, $\quad$ E.2016/125, $\quad$ K.2017/143 sayıl1 kararı. http://kararlaryeni.anayasa.gov.tr/Karar/Content/0556eb9f-017d-4dc4-9060-

0e95c999ccd0? excludeGerekce=False\&wordsOnly=False. Erişim Tarihi: 27 Mayıs 2020. 
38. Anayasa Mahkemesi’nin $\quad 25.10 .2017 \quad$ tarihli, $\quad 2014 / 14189 \quad$ sayılı $\quad$ kararı. http://www.kararlaryeni.anayasa.gov.tr/Content/pdfkarar/2014-14189.pdf. Erişim Tarihi: 30 Mayıs 2020.

39. Danıştay İdari Dava Daireleri Genel Kurulu'nun 9.12.2015 tarihli ve E.2014/2242, K.2015/4991 sayılı kararı. Danıştay Dergisi. https://www.danistay.gov.tr/upload/yayinlar/20_05_2019_042220.pdf. Erişim Tarihi: 18 May1s 2020.

40. Küzeci E. Kişisel Verilerin Korunması. 4.Baskı. İstanbul: Ōn iki leverha yayınları. 2020: 35-100.

41. M.S. v. Sweden, Başvuru No: $20837 / 92$ (1997) http://hudoc.echr.coe.int/app/conversion/pdf/?library=ECHR\&id=00145889\&filename $=001-45889$.pdf\&TID=thkbhnilzk. Erişim Tarihi: 30 Mayıs 2020.

42. L.H. v. Latvia Başvuru No:52019/07 (2014). http://hudoc.echr.coe.int/fre?i=001-142673. Erişim Tarihi: 26 Mayıs 2020.

43. Avcı M. Sağlık hizmetlerinde idarenin mali sorumluluğu. Ankara Barosu Dergisi. 2012;1:105-40.

44. Gözübüyük Ş, Tan T. İdare hukuku - genel esaslar (Cilt 1). 13.Basım. Turhan kitabevi. 2019: 250-320.

45. Anayasa Mahkemesi'nin 20.03.2008 tarihli ve E.2006/167, K.2008/86 sayılı kararı. Anayasa Mahkemesi Kararlar Dergisi. 2012;48(4).

46. Danıştay 15.Dairesi'nin 08.07.2014 tarih ve E. 2014/1150 sayılı kararı. https://www.ido.org.tr/lib_upload/files/Danistay Karari(1).pdf. Erişim Tarihi: 24 Mayıs 2020.

47. Danıştay 10.Dairesi'nin 27.12.2011 tarihli, $\quad$ E.2009/9151, $\quad$ K.2011/5976 sayılı kararı. http://www.kazanci.com/MusePath/kho2/ibb/files/dsp.php?fn=10d-2009-

9151.htm\&kw=Danıştay+10.Daire+\%60E.2009/9151\%60\#fm. Erişim Tarihi: 25 Mayıs 2020.

48. Kişisel Verileri Koruma Kurulu'nun 31/01/2018 tarihli ve 2018/10 sayılı kararı https://www.kvkk.gov.tr/Icerik/4110/201810. Erişim Tarihi: 10 Mayıs 2020. 